\title{
GEOMETRIC MORPHOMETRICS AND FACE SHAPE CHARACTERISTICS ASSOCIATED WITH CHRONIC DISEASE IN THE ELDERLY
}

\author{
MORFOMETRIA GEOMÉTRICA E CARACTERÍSTICAS DA FORMA DA FACE \\ ASSOCIADOS À DOENÇA CRÔNICA EM IDOSOS
}

\section{Lorena Andrade NUNES ${ }^{1}$; Andreia Souza de JESUS² ${ }^{2}$ Cezar Augusto CASOTTI ${ }^{3}$; Edilson Divino de ARAÚJO ${ }^{4}$}

1. Pós-doutoranda do Programa de Pós-Graduação em Enfermagem e Saúde da Universidade Estadual do Sudoeste da Bahia - UESB, Jequié, BA, Brazil; 2. Enfermeira, da Secretaria de Saúde do Município de Wenceslau Guimarães, BA, Brazil; 3. Professor doutor, da Universidade Estadual do Sudoeste da Bahia -UESB, Jequié, BA, Brazil; 4. Professor doutor, da Universidade Federal de Sergipe -

UFS, São Cristóvão, SE, Brazil.

\begin{abstract}
The aging process is something that occurs naturally during the lifetime of the human being. It causes biological, psychological and social changes in the body. Anthropometry, which until the late nineteenth century was a common tool in clinical and taxonomic practices, has gained great importance as a public health measure. This methodology is also important in the evaluation of morbidities in individuals and their social practices. Thus, the objective of the present study was to evaluate facial shape characteristics in the elderly, associated with chronic diseases such as diabetes and hypertension, based on two-dimensional images of the lateral and frontal views of the face. Analysis of discriminant function and cross validation presented significant differences $(\mathrm{p}<0.01)$, for sexual dimorphism in both views and the presence and/or absence of diabetes and hypertension $(\mathrm{p}<0.01)$. For the male sex, the highest classifications were related to the complete lateral and frontal views, in $75.2 \%$ and $81.2 \%$ of cases, respectively. In terms of the female sex, they referred to the frontal view without the orolabial region or jaw $(71.4 \%)$. There was variation in the facial bilateral symmetry in the elderly, with the presence of fluctuating and directional asymmetry $(\mathrm{p}<0.01)$. Despite morphological variations associated with aging, it is possible to use geometric morphometrics techniques to observe characteristics in facial shape related to the presence of diabetes, hypertension, and the presence or absence of both diseases.
\end{abstract}

KEYWORDS: Asymmetry. Diabetes. Face shape. Hypertension. Homo sapiens

\section{INTRODUCTION}

The face is the most viewed region of the body during one's lifetime and plays an important social role related to communication and adaptation of living beings (DARWIN, 2004). It is what distinguishes humans from other life forms and can express emotions, guide behavior, allow reproduction and generate chances of survival (MENDES et al, 2009). Additionally, it is an important way to communicate and shows a fundamental role in human socialization.

In the same way that the face is capable of expressing innumerable feelings and sensations, it can reveal population differences, aid in identification in criminal cases and in some contexts detect the state of health or presence of syndromes (DEMAYO et al, 2009a; HAYES; TULLBERG, 2012; SCOTT et al, 2013; PRASAD et al, 2015). Facial markers associated with computer recognition have generated interest from different disciplines and research areas (MAYER et al, 2017).

Based on morphological characteristics of this region it is possible to identify patterns that can generate knowledge related to human health. Morphometric studies, especially those utilizing geometric morphometrics, have generated quantitative results for shape and size, which are directly interpreted using graphic visualization (ROHLF; MARCUS, 1993; SIĞIRLI; ERCAN, 2013). This technique is defined as a set of methods of acquisition, processing and analysis of shape variables, such that geometrical information from the original data and information for covariation between the landmarks are maintained (ROHLF; MARCUS, 1993; SLICE, 2007).

In geometric morphometrics, the data is obtained using landmarks, whose points follow the rules of homology, that is to say, biological correspondence, which delineate reliable anatomical definitions (SNEATH; SOKAL, 1973; BOOKSTEIN et al, 1985). This homology between landmarks is important to ensure a biological interpretation of the results. The variables are analyzed based on the Generalized Procrustes analysis (ROHLF, 1999), which transforms the configuration of the anatomical landmarks using translation, rescaling and rotation, such that the sum of the squares of the distances between the corresponding points be as small as possible (MONTEIRO; REIS, 1999). 
This methodology has been utilized in diverse areas of human health, using the face for different purposes. From the images, it is possible to detect subtle facial abnormalities in people with epilepsy who carry pathogenesis determined by chromosomal microarrays (CHINTHAPALLI et al, 2012). In a similar manner, Hennessy et al. (2007; 2010) identified subtle facial abnormalities in individuals with schizophrenia and bipolar disorder.

Facial characteristics can indicate the differential effects of hormone exposure during the pre-natal period and of real chromosomal gender, to understand characteristic differences and classify a person as "masculine" or "feminine" and the consequences of perceptions and choice of partner (FINK et al, 2005). In a manner similar to that observed by this author, based on facial geometric morphometrics, it is possible to see that the shape of the face and fingers 2D:4D varies depending on hormonal presence prior to the onset of puberty, which gives the characteristics of masculinity (MEINDL et al, 2012). Additionally, the shape of the face is associated with the body mass index (BMI) and the waist-hip ratio (WHR), as verified by Mayer et al (2017) in a sample of youths from Central Europe, utilizing facial imaging and geometric morphometrics. The faces of women with an elevated BMI had a broader, rounder facial contour in relation to the size of the eyes and lips and relatively lower eyebrows.

Other applications of this methodology are in Odontology, and plastic, craniomaxillofacial, and otorhinolaryngology surgeries, which are increasingly interested in new technologies to promote correct diagnosis and prepare patient treatment plans, including for the diagnosis of congenital and acquired malformations (MENEZES; SFORZA, 2010). However, while studies utilizing facial patterns have been carried out using adolescent and/or adult individuals, there are no studies associated with facial shape patterns in the diagnosis of diseases in elderly individuals. The aging process is slow, progressive and irreversible, and provokes biological, psychological and social changes. The face is one of the areas where this process and the consequences of the passage of time is most noticeable (KEDE; SABATOVICH, 2004; FERNANDES; ASSUNÇÃO, 2011; SANTOSFILHO; FERREIRA, 2016).

Therefore, the aim of this study was to verify if there is a facial morphological pattern in the elderly associated with chronic diseases such as diabetes and hypertension, despite the facial variations, which occur due to the aging process. The general hypothesis tested in this study excludes the effects of allometry and sexual dimorphism, making it possible to find specific patterns in order to form distinct groups of individuals according to the presence and / or absence of chronic diseases: diabetes and / or hypertension.

\section{MATERIAL AND METHODS}

After the approval of the project by the Ethics Committee (CAAE 56017816.2.0000.0055), elderly residents from the municipality of AiquaraBA, were submitted to the Mini Exam for Jawal State test (FOLSTEIN et al., 1975), prior to applying morphometric testing as an exclusion criterion. This is because neurological and psychiatric diseases can lead to variations in facial shape (HENNESSY et al, 2005; CHINTHAPALLI et al, 2012). The individuals presented diabetes, hypertension, and the presence or absence of both diseases (diabetes/hypertension).

For the analysis of the lateral view, 206 elderly people, 119 female and 87 male, participated. For the analysis of the frontal view, 209 elderly people, 121 female and 88 male, participated. They had ages varying from 60 to 95 years of age and an average of 71 years. The data was collected in 2016 in the city of Aiquara - BA. The images were obtained using a digital Canon SX60HS camera, with the individuals seated at a distance of $1.5 \mathrm{~m}$. Participants were instructed to maintain a neutral expression, mouth closed and eyes to the front, with adjustment according to the Frankfurt horizontal plane. Additionally, a scale bar to the side of the head was used and individuals were identified. Participants used no make-up or glasses. Additionally, the photos were taken in a well-lit environment, using the flash where necessary, avoiding problems of shadowing and consequently with measurement.

For the lateral view, 4 landmarks and 19 semilandmarks were used and for the frontal view 10 landmarks and 12 semilandmarks in areas that characterized the differences in the structure of the human face using the TpsDig2 program (ROHLF, 2015) (Table 1; Figure 1). These landmarks were selected with the aim of determining the facial variation associated with the identification of the presence or absence of the diseases tested, and to minimize the effects related to the aging process. The semi-landmarks were submitted to the adjustment process using the TpsRelw program, equalizing the distances over the curves. These were placed so as to minimize the differences in shape of the individuals in relation to the average shape (BOOKSTEIN, 1997; GUNZ; MITTEROECKER, 
2013). All measurements were carried out by the

A

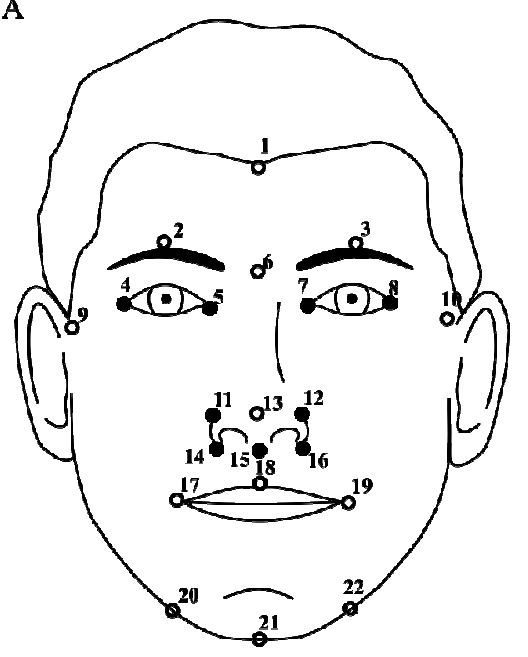

same person to avoid errors between observers.

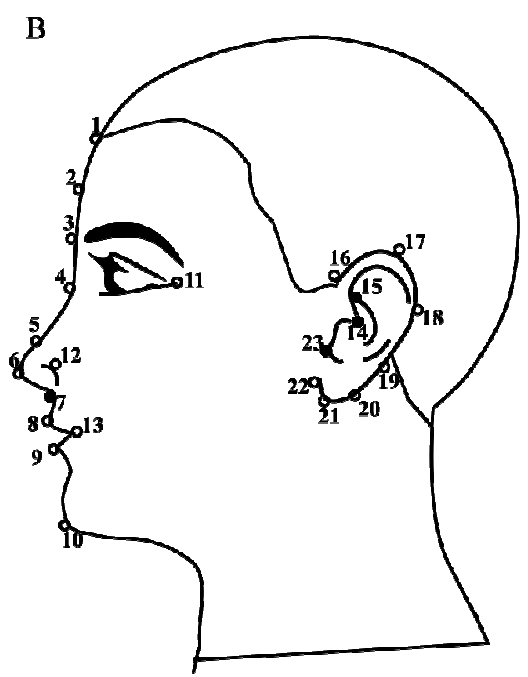

Figure 1. Scheme of the frontal (A) and lateral (B) views with the localization of the landmarks (filled in points) and semilandmarks (empty points) used for facial differentiation.

Table 1. Description of the landdmarks and semilandmarks used in the faces of the elderly for morphometric analysis.

\begin{tabular}{|c|c|c|c|c|}
\hline \multirow{2}{*}{$\begin{array}{l}\text { Landmark } \\
\text { s }\end{array}$} & \multicolumn{4}{|c|}{ Description and types of the landmarks and semilandmarks } \\
\hline & Type & Frontal view & Type & Lateral view \\
\hline 1 & III & Trichion & III & Trichion \\
\hline 2 & III & $\begin{array}{l}\text { Highest point at the top edge of } \\
\text { the midline portion of the } \\
\text { eyebrow (left) }\end{array}$ & III & The midpoint of the forehead \\
\hline 3 & III & $\begin{array}{l}\text { Highest point at the top edge of } \\
\text { the midline portion of the } \\
\text { eyebrow (right) }\end{array}$ & III & Glabella \\
\hline 4 & I & $\begin{array}{l}\text { Distal bending of the eyelid of the } \\
\text { left eye }\end{array}$ & III & $\begin{array}{l}\text { The deepest point of the } \\
\text { nasofrontal region }\end{array}$ \\
\hline 5 & I & $\begin{array}{l}\text { Mesial bending of the eyelid of } \\
\text { the left eye }\end{array}$ & III & Midnasale \\
\hline 6 & III & Glabella & III & Pronasale \\
\hline 7 & I & $\begin{array}{l}\text { Mesial bending of the eyelid of } \\
\text { the right eye }\end{array}$ & $\mathrm{I}$ & Subnasale \\
\hline 8 & I & Distal eyelid flap of the right eye & III & $\begin{array}{l}\text { The midpoint of the border of the } \\
\text { labiare superius }\end{array}$ \\
\hline 9 & III & Left zygomatic region & III & $\begin{array}{l}\text { The midpoint of the border of the } \\
\text { bottom lip }\end{array}$ \\
\hline 10 & III & Right zygomatic region & III & Gnathion \\
\hline 11 & I & $\begin{array}{l}\text { Most lateral point on the left nasal } \\
\text { ala }\end{array}$ & III & Distal eyelid flap of the right eye \\
\hline 12 & I & $\begin{array}{l}\text { Most lateral point on the right } \\
\text { nasal ala }\end{array}$ & III & Most lateral point on the nasal ala \\
\hline 13 & III & Pronasale & III & $\begin{array}{l}\text { Most lateral point where the } \\
\text { upper and lower lib meet }\end{array}$ \\
\hline 14 & I & $\begin{array}{l}\text { Most lateral point of the nose } \\
\text { (left) }\end{array}$ & I & Tragus auricular curvature \\
\hline 15 & I & Subnasale & I & Antihelix start \\
\hline 16 & $\mathrm{I}$ & $\begin{array}{l}\text { Most lateral point of the nose } \\
\text { (right) }\end{array}$ & III & Ear contour \\
\hline
\end{tabular}




\begin{tabular}{|c|c|c|c|c|}
\hline 17 & III & $\begin{array}{l}\text { Most lateral point where the upper } \\
\text { and lower lib meet (left) }\end{array}$ & III & Ear contour \\
\hline 18 & III & $\begin{array}{l}\text { The midpoint of the border of the } \\
\text { labiare superius }\end{array}$ & III & Ear contour \\
\hline 19 & III & $\begin{array}{l}\text { Most lateral point where the upper } \\
\text { and lower lib meet (right) }\end{array}$ & III & Ear contour \\
\hline 20 & III & $\begin{array}{l}\text { Protrusion of the mental tubercle } \\
\text { (left) }\end{array}$ & III & Contour of the earlobe \\
\hline 21 & III & Gnathion & III & Contour of the earlobe \\
\hline 22 & III & $\begin{array}{l}\text { Protrusion of the mental tubercle } \\
\text { (right) }\end{array}$ & III & Contour of the earlobe \\
\hline 23 & --- & --- - & $\mathrm{I}$ & Intertragic notch \\
\hline
\end{tabular}

Based on the Cartesian coordinates obtained, the data was submitted to Generalized Procrustes analysis with the aim of eliminating the effects of scale, rotation and translation and to obtain the average shape of the face. A preliminary test was carried out based on the Procrustes ANOVA, to find out if there were measuring errors associated with the measurer. In this manner, measurements were carried out in duplicate (PALMER, 1994).

A regression analysis was conducted, to verify and correct the allometry effect, especially due to the effects of the aging process. Following this, the correlation analysis, discriminating function, cross validation and $\mathrm{D}^{2}$ Mahalanobis distance and Thin-Plate Sline were carried out. These analyses were undertaken using the MorphoJ program (KLINGENBERG, 2011). Differences associated with sexual dimorphism and edentulism were also tested for. Subsequently, we investigated if there were symmetrical facial variations for the frontal view or fluctuating and directional asymmetry, using Procrustes ANOVA for each individual. Subsequently an analysis of variance (ANOVA) was realized to verify if the diseases interfered with characteristics of facial symmetry. To verify facial symmetry, the landmarks from one side were corresponded with those on the other side along a medial plane (KLINGENBERG et al, 2002).

\section{RESULTS}

From the Procrustes ANOVA, an absence of variation associated with measurement errors was found, therefore, the analyses were performed. Based on the regression to test the presence or not of allometry, significant values for the frontal and lateral views $(\mathrm{p}<0.01)$ were observed. Therefore, the face shape, in both the lateral and frontal views, is modified as a function of size. Thus, the data without the allometry effect was used and the analysis of facial shape was conducted.
Different ethnic groups were evaluated and differences associated with ethnicity were not observed. In the discriminating function, significant differences $(p<0.01)$ were observed in terms of sexual dimorphism both for the frontal and lateral views. Therefore, females and males were analyzed separately to only verify the effect of the variation of facial shape based on the presence of absence of diabetes and/or hypertension. However, in individuals, the whole face was analyzed as well as without the jaw and orolabial region, given that these regions suffer intense morphological alteration with age, despite significant values associated with edentulism not being observed $(\mathrm{p}<0.01)$.

Within each sex, when evaluating the facial shape with or without the orolabial region, significant differences were encountered $(p<0.01)$ using the discriminating function related to the chronic diseases for both views. Based on these results, cross validation was carried out with the aim of determining to what extent individuals were correctly classified within each group.

Considering the male sex, from the complete frontal view, individuals were correctly classified in $75.2 \%$ of cases, while from this same view without the orolabial region and jaw the classification was $72.4 \%$. In the complete lateral view and without the orolabial region and jaw there was $81.2 \%$ and $66.3 \%$ of correct classification for each group, respectively. For females, individuals were classified correctly in $62.8 \%$ of cases for the complete frontal view and $71.4 \%$ without the orolabial region and jaw. In the lateral view, the classification was $68.5 \%$ for the complete view and $67 \%$ for the view without orolabial region or jaw.

Based on the better classification by cross validation, the $\mathrm{D}^{2}$ Mahalanobis distance was obtained from 10,000 permutations. For the male frontal view, significant values $(\mathrm{p}>0.05)$ were not observed only with facial shape between individuals with hypertension and hypertension and diabetes, as well as presenting a shorter Mahalanobis distance. 
The greater facial morphological distance was between individuals with an absence of these diseases and diabetics (Table 2). However, for the complete lateral view, significant differences were found comparing all the groups, where the smaller distance was between individuals without presence of either disease and the greater distance was between those who presented both diseases and the diabetics (Table 2).

Table 2. $\mathrm{D}^{2}$ Mahalanobis distance matrix in the lower half of the table and significance value with 10,000 replications, referent to the complete masculine frontal and lateral views.

\begin{tabular}{|c|c|c|c|c|}
\hline Frontal view & $\begin{array}{l}\begin{array}{l}\text { Presence of both } \\
\text { diseases }\end{array} \\
\end{array}$ & $\begin{array}{l}\text { Absence of both } \\
\text { diseases }\end{array}$ & Diabetes & Hypertension \\
\hline $\begin{array}{l}\text { Presence of both } \\
\text { diseases }\end{array}$ & & $<.0001 * *$ & $0.0138 *$ & $0.0696^{\mathrm{ns}}$ \\
\hline $\begin{array}{l}\text { Absence of both } \\
\text { diseases }\end{array}$ & 3.3491 & & $<.0001 * *$ & $<.0001 * *$ \\
\hline Diabetes & 3.6736 & 4.4913 & & $0.0001 * *$ \\
\hline Hypertension & 1.7518 & 2.2127 & 3.7255 & \\
\hline \multicolumn{5}{|l|}{ Lateral view } \\
\hline $\begin{array}{l}\text { Presence } \\
\text { of both diseases }\end{array}$ & & $<.0001 * *$ & $0.0002 * *$ & $<.0001 * *$ \\
\hline $\begin{array}{l}\text { Absence of both } \\
\text { diseases }\end{array}$ & 3.6676 & & $<.0001 * *$ & $0.0162 *$ \\
\hline Diabetes & 6.1049 & 6.1005 & & $<.0001 * *$ \\
\hline Hypertension & 3.4133 & 1.7778 & 6.275 & \\
\hline
\end{tabular}

ns - not significant $; *$ significant $\mathrm{p}>0.05 ; * *$ significant $\mathrm{p}>0.01$

For the lateral female view without the orolabial region or jaw, significant values $(\mathrm{p}<0.05)$ were also observed for all the groups. The greatest distance was between those who did not present both diseases and diabetic individuals, and the least distance was between those individuals with both diseases and those with hypertension. These results were similar to those found in males in the frontal view (Table 3).

Table 3. $\mathrm{D}^{2}$ Mahalanobis distance matrix in the lower half of the table and significance value with 10,000 replications in the upper part, referent to the lateral female view with the orobial and jaw.

\begin{tabular}{llllll}
\hline & & $\begin{array}{l}\text { Presence of both } \\
\text { diseases }\end{array}$ & $\begin{array}{l}\text { Absence of both } \\
\text { diseases }\end{array}$ & Diabetes & Hypertension \\
\hline $\begin{array}{l}\text { Presence of both } \\
\text { diseases }\end{array}$ & & $0.0115^{*}$ & $0.0172^{*}$ & $0.0184^{*}$ \\
$\begin{array}{l}\text { Absence } \\
\text { diseases }\end{array}$ & & & $0.0001^{* *}$ & $0.0068^{* *}$ \\
$\begin{array}{l}\text { Diabetes } \\
\text { Hypertension }\end{array}$ & $\begin{array}{l}1.4302 \\
\mathbf{1 . 2 9 4 8}\end{array}$ & $\mathbf{3 . 0 4 1 1}$ & & $0.0001^{* *}$ \\
\hline
\end{tabular}

* significant $\mathrm{p}>0.05$; ** significant $\mathrm{p}>0.01$;

Based on the thin-plate spline, it is possible to verify the change of form between the groups analyzed. For the frontal view it is possible to observe that in individuals who present diabetes, the region of the zygomatic arch tends to expand, while in those who present hypertension the nasal region and the jaw tends to expand, giving the face a "full moon" shape as reported by some researchers (DBH VI, 2010; OIGMAN, 2014). In individuals who present both diseases, the face shows the characteristics associated with diabetes and hypertension patients, with some widening in the region of the zygomatic arch and the jaw. Those who did not present both diseases, have a facial shape closer to the average, presenting fewer variations (Figure 2).

For the lateral view, individuals who presented diabetes presented shortening in the nasal region and contraction in the region of the ear at the beginning of the anther branch in relation to the auricular form, while the individuals with hypertension had a shape opposed to that of 
diabetics. Evidence of differences in the shape of the lateral view between hypertension patients and individuals who did not present both diseases was not observed. Those simultaneously presenting hypertension and diabetes, in a manner similar to those in the frontal view, presented characteristics for shape both of hypertension patients (expansion in the auricular region) and for diabetics (contraction in the nasal region) (Figure 3).
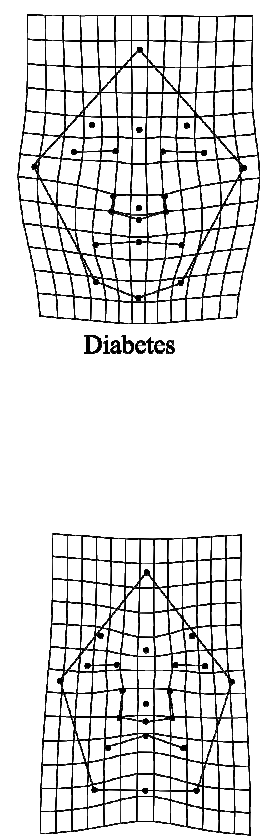

Presence of both disease
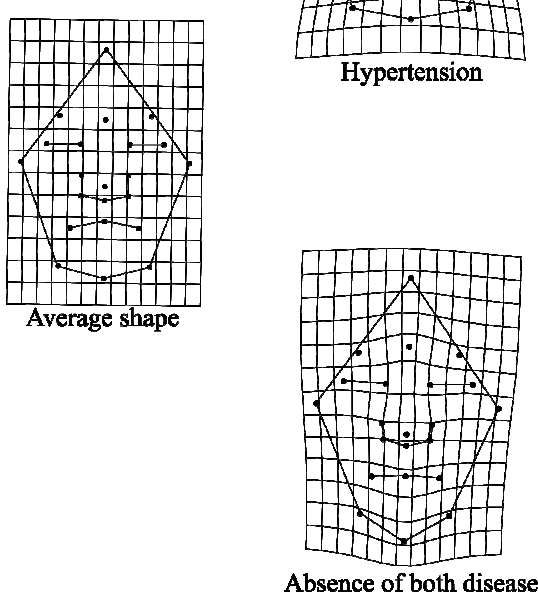

Figure 2. Thin-plate spline demonstrating the variation in the frontal face shape based on the average shape for individuals with diabetes, hypertension and presence or absence of both diseases.

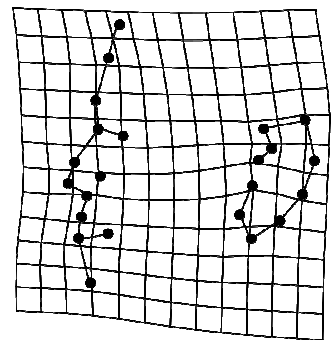

Diabetes

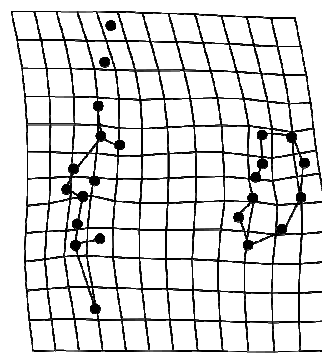

Presence of both disease

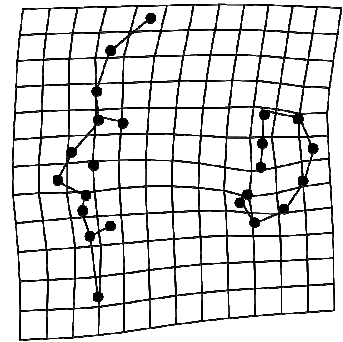

Hypertension

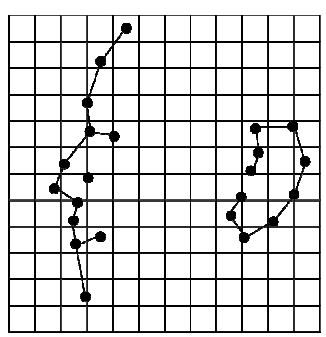

Average shape

Figure 3. Thin-plate spline showing the variation in face shape in the lateral view based on the average shape for individuals with diabetes, hypertension and presence or absence of both diseases. 
Significant values for the asymmetry characteristics for facial shape $(p<0.001)$ were observed. The elderly presented fluctuating asymmetry with significant values for the side relation by individual $(\mathrm{p}<0.001)$ and directional asymmetry associated with the side effect $(p<0.001)$. Despite the presence of facial symmetry, significant values related to the presence or absence of diseases were not encountered $(\mathrm{p}<0.05)$. However, it was observed that individuals who present hypertension have a tendency to show greater variation in facial symmetry, while individuals who do not present both diseases have less facial symmetry (Figure 4).

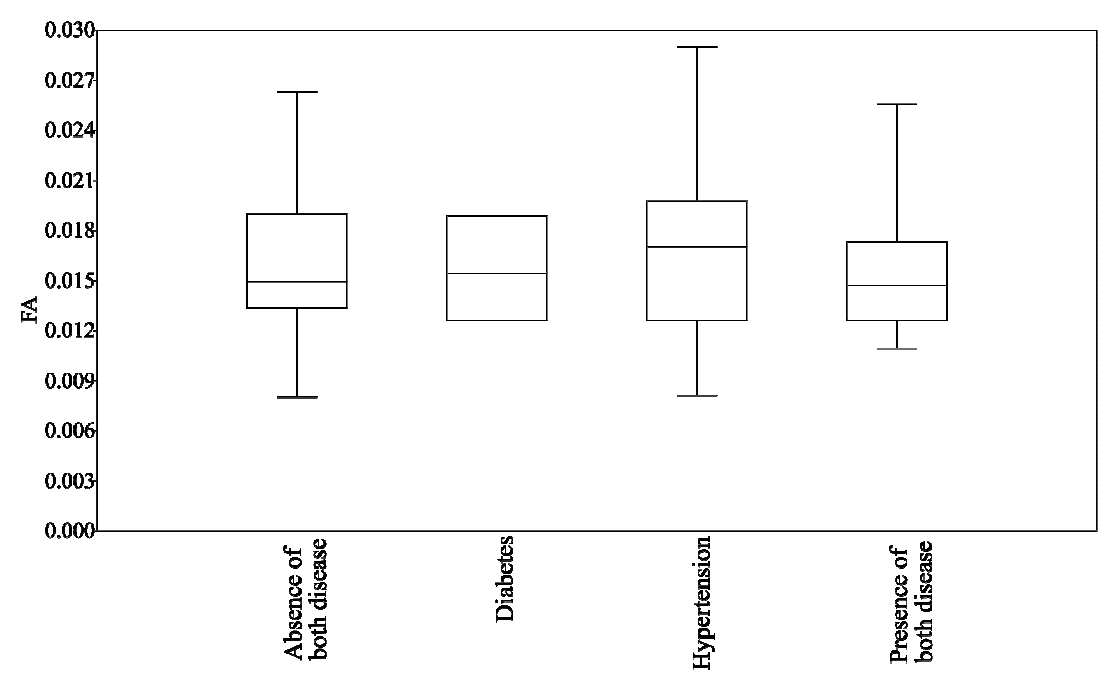

Figura 4. Boxplot indicating the highest and lowest indices of asymmetry based on facial shape in elderlypeople with diabetes, hypertension or with presence or absence of both diseases.

\section{DISCUSSION}

During the aging process, it is natural that phenotypic facial changes take place. Time can influence the size and shape of the nose, such as the tendency for growth and rotation of the tip, and the action of gravity itself. Gradual reduction in muscle mass can also interfere in the variability of facial shape (SANTOS-FILHO; FERREIRA, 2016). Facial allometry in humans can be an important factor for confusion in studies related to facial perception and even the choice of partner. These changes are especially associated to the masculine face (MITTEROECKER et al, 2013).

Morphological differences associated with sexual dimorphism were also encountered by other researchers. Scott et al. (2010) verified the association between sexual dimorphism and attraction to masculine faces and the prediction of the choice of partners. Claes et al (2012) verified significant sexual dimorphism in young adults between 18-25 years. In a similar manner, Mitteroecker et al (2015) verified the facial differences associated with sexes and further still the different degrees of masculinity based on facial shape and partner preferences.

Beyond these differences between the sexes, the orolabial region is one of those, which most suffers transformations associated with time of life, with a tendency for the lips to become thinner and a loss of elasticity in muscles and collagen. The region of the jaw under the influence of gravity can also alter the facial shape over time (SANTOSFILHO; FERREIRA, 2016).

Despite the effects caused by aging principally in the orolabial region as reported by Santos-Filho and Ferreira (2016), the lower result for the analyses of the orolabial region, indicate that the complete evaluation of the face still has better results in comparison with the analyses without this region, especially because the morphological variation for individuals who have hypertension is mainly located in the region of the menton that is in the orolabial region.

From the greater values obtained through cross validation, it is possible to observe that male individuals present morphological characteristics that more clearly relate to the presence of diseases such as diabetes and hypertension. Additionally, the face as a whole, in both the views, were those that most contributed to the separation of the groups, diabetics, those with hypertension, or the presence or absence of both diseases. In women, the best parameter for the identification of the chronic diseases is the frontal view without the orolabial region or jaw. Demayo et al (2009b) verified variations in face shape between diabetic and nondiabetic adults. Additionally, it is inferred that the 
geometric morphometrics is effective to describe the facial shape between individuals who present this disease and that this technique can be utilized to describe the facial shape with the aim of identifying specific health problems.

Diabetes mellitus and systemic arterial hypertension are diseases that generally increase at more advanced ages and are one of the main causes of mortality around the world (CRUZERA; UTIMURA; ZATZ, 1998). Arterial hypertension normally generates changes in the facial region frequently making it rounder (DBH VI, 2010) while diabetes normally generates edemas due to the accumulation of bodily fluids (ANWER et al 2011), and these characteristics are frequently visible in the facial region.

A study carried out by Scott et al (2015) found that the quotient of the autism spectrum is identified with greater ease in the facial shape of individuals of the male sex, compared with females. Men were identified in $69 \%$ of cases while women in only $47 \%$. Demayo et al. (2009a) found differentiated grouping characteristics from the facial shape of each sex, with the discriminating analysis for the male population being classified correctly in $91.1 \%$ of cases and in females in $94.4 \%$. This demonstrates that facial analysis of both sexes is important given that they can present difference characteristics and responses in a diversity of analyses.

These differences in facial characteristics between men and women can be related to life style associated with each sex. Men show fewer health problems, ingest fewer medications and tend to have a better quality of life in comparison with women due to being more accepting of the physical changes associated with aging (GUIOMAR, 2012). The life process of women shows a greater preoccupation with children. Additionally, they do not have the same opportunities or access to education, schooling or profession, they frequently abdicate their freedom, and these tiring, day-to-day factors associated can accelerate the aging process (FIGUEIREDO et al., 2007; PLONER et al., 2008). However, women worry more about their appearance in comparison to men, being more demanding, presenting characteristics of vanity and being more worried about the standard (LIMOEIRO, 2012). All these variables can interfere in some way, in the differences between the sexes associated with facial morphological variations and chronic diseases.

With these results it is possible to observe that there are morphological facial differences between elderly individuals who show the presence or absence of both diseases. According to Pound et al. (2014), facial symmetry can indicate physiological health and interfere in the selection and choice of partners, despite not having observed facial variation due to health in children.

Facial asymmetry is also common amongst individuals, as was seen by Demayo et al. (2009b). These researchers identified asymmetry in the facial region between individuals who presented or not diabetes, observing a lengthening toward the right side, an inclination of the peak of the forehead and a compression of the face in the direction of the center. Evaluating population differences in Filipino indigenous groups Demayo et al. (2009a) found variations in facial symmetry for both sexes, the results corroborating with those found in this study, which presented fluctuating asymmetry and directional asymmetry. Solon et al. (2013) found high levels of fluctuating asymmetry between youths and adults with the presence of hypertension when comparing individuals who did not present this disease.

Despite facial variations occurring due to human aging, it was possible to observe changes in facial characteristics in the elderly with chronic diseases such as diabetes and hypertension. Up to 60 years of age, the studies associated with human aging were almost exclusively directed toward fragility, loss and decline (GUIOMAR, 2012). The social representation of old age is associated with a loss of vitality, tiredness, disease, incapacity and many other negative aspects (PLONER et al, 2008). However, there are also socio-political changes, especially related to health and quality of life generating a new profile for aging and a tendency to search for new understandings in terms of the life of the elderly, especially associated with greater longevity and better conditions of life (GUIOMAR, 2012).

The main limitations of the study were due to the limited number of anatomical landmarks to be chosen due facial aging process which is reflected in a reduction in the number of variables analyzed. This limited us to an evaluation of the internal structures. Additionally, the transversal delineation of this study presented a limitation, which did not allow inferences regarding the causality of the associations observed. However, despite these factors, with the number of anatomical landmarks utilized, it was possible to observe that even with these limitations, we were able to determine the changes in shape between the groups of individuals evaluated.

Studies such as the present one can contribute to the development of diagnostic 
morphometric methods for precocious diseases, based on new methods and techniques as well as try to contribute to treatments, in this way improving the quality of life of these individuals. However, further research is necessary to confirm the possibility of the use of geometric morphometrics in the identification of precocious diseases.

\section{ACKNOWLEDGMENTS}

Research Program for SUS (FAPESB / PPSUS) financial support, grant term SUS0055/2013. And by the scholarship of the National Postdoctoral Program of CAPES for the author Lorena Andrade Nunes

RESUMO: O processo de envelhecimento é algo que ocorre naturalmente durante a vida do ser humano. Isso causa mudanças biológicas, psicológicas e sociais no corpo. A antropometria, que até o final do século XIX foi uma ferramenta comum em práticas clínicas e taxonômicas, e ganhou uma grande importância como medidas de saúde pública. Esta metodologia também é importante na avaliação de morbidades nos indivíduos e suas práticas sociais. Assim, o objetivo do presente estudo foi avaliar características da forma facial em idosos, associados a doenças crônicas como diabetes e hipertensão, com base em imagens bidimensionais das vistas lateral e frontal do rosto. A análise da função discriminante e da validação cruzada apresentou diferenças significativas $(p<0,01)$, para o dimorfismo sexual em ambos os pontos de vista e a presença e/ou ausência de diabetes e hipertensão ( $\mathrm{p}<0,01$ ). Para o sexo masculino, as classificações mais elevadas foram relacionadas às vistas laterais e frontais completas, em 75,2\% e 81,2\% dos casos, respectivamente. Para o sexo feminino, os resultados para a vista visão frontal sem a região orelabial ou maxilar foi de $71,4 \%$. Houve variação na simetria facial bilateral dos idosos, com presença de assimetria flutuante e direcional $(p<0,01)$. Apesar das variações morfológicas associadas ao envelhecimento, através de técnicas de morfometria geométrica é possível observar uma característica na forma facial em relação à diabetes, hipertensão e presença ou ausência de ambas as doenças.

PALAVAS-CHAVE: Assimetria. Diabetes. Forma da face. Hipertensão. Homo sapiens

\section{REFERENCES}

ANWER, Z.; SHARMA, K.; GARG, V. K.; KUMAR, N.; KUMARI, A. Hypertension management in diabetic patients. Eur Rev Med Pharmacol Sci. v. 15, p. 1256-63, 2011.

BOOKSTEIN, F. Landmark methods for forms without landmarks: morphometrics of group differences in outline shape. Med. Image Anal. v. 1, n. 3, p. 225-43, Apr. 1997. https://doi.org/10.1016/S1361-

8415(97)85012-8

BOOKSTEIN, F. L.; CHERNOFF, B.; ELDER, R. L.; HUMPHRIES. J. J. M.; SMITH, G. R.; STRAUSS, R. E. Morphometrics in evolutionary biology. Special publication 15. Penn: Acad Nat Sci, Philadelphia, 1985. 277 .

CHINTHAPALLI, K.; BARTOLINI, E.; NOVY, J.; SUTTIE, M.; MARINI, C.; FALCHI, M.; FOX, Z.; CLAYTON, L. M. S.; SANDER, J. W.; GUERRINI, R.; DEPONDT, C.; HENNEKAM, R.; HAMMOND, P.; SISODIYA, S. M. Atypical face shape and genomic structural variants in epilepsy. Brain. v. 135, n. 10, p. 3101-3114, Oct. 2012. https://doi.org/10.1093/brain/aws232

CLAES, P.; WALTERS, M.; SHRIVER, M. D.; PUTS, D.; GIBSON, G.; CLEMENT, J.; BAYNAM, G.; VERBEKE, G.; VANDERMEULEN, D.; SUETENS, P. Sexual dimorphism in multiple aspects of 3D facial symmetry and asymmetry defined by spatially dense geometric morphometrics. J. Anat. v. 221, n. 2, p. 97 114, Aug. 2012. https://doi.org/10.1111/j.1469-7580.2012.01528.x

CRUZERA, A. B.; UTIMURA, R.; ZATZ, R. A hipertensão no diabete. HiperAtivo. v. 5, n. 10 p. 261-6, 1998.

DARWIN, Charles. A expressão das emoções no homem e nos animais. Tradução: Leon de Souza Lobo Garcia, São Paulo: Companhia das Letras, 2004. 344p. 
DBH. VI Diretrizes Brasileiras de Hipertensão. VI Diretrizes Bras Hipertens - Soc Bras Cardiol [Internet]. v. 95, p. 1-51 2010. Disponível em: http://bvsms.saude.gov.br/bvs/publicacoes/caderno_ atencao_basica_n1_p1.pdf. Acesso em: 27 abr. 2017

DEMAYO, C.; TORRES, M.; OLVIS, P.; MANLEGRO, N. Face Shape Differences in Selected Indigenous Peoples' Groups in Mindanao. Philippines. IJBA. v. 4, n. 1, p. 1-9, 2009a.

DEMAYO, C.; TORRES, M.; VEÑA, C.; Face Shapes Of Diabetics And Non-Diabetics Described Using Geometric Morphometrics. The Internet J of Endocrinology, v. 6, n. 1, p. 1-6. 2009 b.

FERNANDES, M. J. S.; ASSUNÇÃO, F.F. de O. Efeito da Microdermoabrasão no Envelhecimento Facial. Rev Inspirar Mov Saude v. 3, n.3, p. 18-23, mai/jun. 2011.

FIGUEIREDO, M. L. F.; TYRREL, M. A. R.; CARVALHO, C. M. R. G.; LUZ, M. H. B. A.; AMORIM, F. C. M.; LOIOLA, N. L. de A. As diferenças de gênero na velhice. Rev. Bras. Enferm. v. 60, n. 4, p. 422-7, July/Aug. 2007. https://doi.org/10.1590/S0034-71672007000400012

FINK, B.; GRAMMER, K.; MITTEROECKER, P.; GUNZ, P.; SCHAEFER, K.; BOOKSTEIN, F. L.; MANNING, J. T. Second to fourth digit ratio and face shape. Proc. R. Soc. B. n. 272, n. 1576, p. 1995-2001, oct. 2005. https://doi.org/10.1098/rspb.2011.2351

FOLSTEIN, M. F.; FOLSTEIN, S. E.; MCHUGH, P. R. "Mini-mental state". A practical method for grading the cognitive state of patients for the clinician. J. Psychiatr. Res. v. 12, n.3, p. 189-98, nov. 1975. https://doi.org/10.1016/0022-3956(75)90026-6

GUIOMAR, V. C. R. V. Diferenças de gênero no viver o envelhecimento. Psicologia.pt,. 2012. Disponível em: http://www.psicologia.pt/artigos/textos/TL0262.pdf Acesso em: 05 jul. 2017.

GUNZ, P.; MITTEROECKER, P. Semilandmarks: A Method for Quantifying Curves and Surfaces. Hystrix n. 24, n. 1, p. 103-109, 2013. http://dx.doi.org/10.4404/hystrix-24.1-6292

HAYES, S.; TULLBERG, C. Police Witness Identification Images: A geometric morphometric analysis. J. Forensic. Sci. v. 57, n. 6, p. 1487-1494, nov. 2012. https://doi.org/10.1111/j.1556-4029.2012.02168.x

HENNESSY, R. J.; MCLEARIE, S.; KINSELLA, A.; WADDINGTON, J. L. Facial surface analysis by 3D laser scanning and geometric morphometrics in relation to sexual dimorphism in cerebral-craniofacial morphogenesis and cognitive function. J. Anat. v.207, n. 3, p. 283-295, Sep. 2005.

https://doi.org/10.1111/j.1469-7580.2005.00444.x

HENNESSY, R. J.; BALDWIN, P. A.; BROWNE, D. J.; KINSELLA, A.; WADDINGTON, J. L. Threedimensional laser surface imaging and geometric morphometrics resolve frontonasal dysmorphology in schizophrenia. Biol. Psychiatry. v.61, n. 10, p. 1187-1194, may. 2007.

https://doi.org/10.1016/j.biopsych.2006.08.045

HENNESSY, R. J.; BALDWIN, P. A.; BROWNE, D. J.; KINSELLA, A.; WADDINGTON, J. L. Frontonasal dysmorphology in bipolar disorder by 3D laser surface imaging and geometric morphometrics: comparisons with schizophrenia. Schizophr Res v. 122, n. 1-3, p. 63-71. sep. 2010.

https://doi.org/10.1016/j.schres.2010.05.001

KEDE, M. P. V.; SABATOVICH, O. Dermatologia Estética. São Paulo: Atheneu 2004, 771p.

KLINGENBERG, C. P.; BARLUENGA, M.; MEYER, A. Shape analysis of symmetric structures: quantifying variation among individuals and asymmetry. Evolution v. 56, n. 10, p. 1909-1920, oct. 2002. https://doi.org/10.1111/j.0014-3820.2002.tb00117.x 
KLINGENBERG, C. P. MorphoJ: In integrated software package for geometric morphometrics. Mol Ecol. Resour. v. 11, n. 2, p. 353-357. mar. 2011. https://doi.org/10.1111/j.1755-0998.2010.02924.x

LIMOEIRO, B. C. O corpo em foco: envelhecimento e diferenças de gênero na cidade do rio de janeiro.

Revista Todavia 3, 69-79. 2012.

MAYER, C.; WINDHAGER, S.; SCHAEFER, K.; MITTEROECKER, P. BMI and WHR Are Reflected in Female Facial Shape and Texture: A Geometric Morphometric Image Analysis. PLoS One. 9, 12(2), e0172205, jan. 2017. https://doi.org/10.1371/journal.pone.0169336

MEINDL, K.; WINDHAGER, S.; WALLNER, B.; SCHAEFER, K. Second-to-fourth digit ratio and facial shape in boys: the lower the digit ratio, the more robust the face. Proc. R. Soc. B v. 279, n. 1737, p. $2457-$ 2463. jun. 2012. https://doi.org/10.1098/rspb.2011.2351

MENDES, D. M. L. F.; SEIDL-DE-MOURA, M. L.; SIQUEIRA, J. D. O. The ontogenesis of smiling and its association with mothers' affective behaviors: A longitudinal study. Infant. Behav. Dev. v. 32, n. 4, p. 445453, dec. 2009. https://doi.org/10.1016/j.infbeh.2009.07.004

MENEZES, M.; SFORZA, C. Morfometria tridimensional (3D) da face. Dental. Press. J. Orthod. v. 15, n. 1, p. 13-15, Jan./Feb. 2010.

MITTEROECKER P, GUNZ P, WINDHAGER S, SCHAEFER, K. A brief review of shape. form. and allometry in geometric morphometrics. with applications to human facial morphology. Hystrix v. 24, n. 1, p. 59-66, 2013. http://dx.doi.org/10.4404/hystrix-24.1-6369 https://doi.org/10.1590/S2176-94512010000100002

MITTEROECKER, P.; WINDHAGER, S.; MÜLLER, G. B.; SCHAEFER, K. The Morphometrics of "Masculinity" in Human Faces. PLoS ONE v. 10, n. 2, e0118374. 2015. https://doi.org/10.1371/ journal.pone.0118374.

MONTEIRO, L. R.; REIS, S. F. Princípios de morfometria geométrica. Ribeirão Preto: Holos. 1999, 188p.

PALMER, A. R. Fluctuating asymmetry analyses: A primer. In: Developmental Instability: Its Origins and Evolutionary Implications. Dordrecht. The Netherlands: Kluwer Academic Publishers. p. 335-364. 1994. https://doi.org/10.1007/978-94-011-0830-0_26

PLONER, K. S.; MICHELS, L. R. F.; OLIVEIRA, M. A. M.; STREY, M. N. O significado de envelhecer para homens e mulheres. Silveira AF., et al., org. Cidadania e participação social [online]. Rio de Janeiro: Centro Edelstein de Pesquisas Sociais. p. 142-158 2008. Disponível em: http://books.scielo.org/id/hn3q6/pdf/silveira9788599662885-14.pdf

POUND, N.; LAWSON, D. W.; TOMA, A. M.; RICHMOND, S.; ZHUROV, A. I.; PENTON-VOAK, I. S. Facial fluctuating asymmetry is not associated with childhood ill-health in a large British cohort study. Proc. $\mathbf{R}$ . Soc. B. v. 281, p. 1-7, Aug. 2014. https://doi.org/10.1098/rspb.2014.1639.

PRASAD, S.; KATINA, S.; HENNESSY, R. J.; MURPHY, K. C.; BOWMAN, A. W.; WADDINGTON, J. L. Craniofacial Dysmorphology in 22q11.2 Deletion Syndrome by 3D Laser Surface Imaging and Geometric Morphometrics: Illuminating the Developmental Relationship to Risk for Psychosis. Am. J. Med. Genet. A 167A, n3, p. 529-36, mar. 2015. https://doi.org/ 10.1002/ajmg.a.36893

ROHLF, F. J.; MARCUS, L. F. A revolution in morphometrics. Tree v. 8, n. 4, p. 129-132, apr. 1993. https://doi.org/10.1016/0169-5347(93)90024-J

ROHLF, F. J. Shape statistics: Procrustes superimpositions and tangent spaces. J. of Classification v. 16, n. 2, p. 197-223, july. 1999 
ROHLF, F. J. tpsDig2 Version 2.22. Ecology \& Evolution. SUNY at Stony Brook. 2015

SANTOS-FILHO, E. F.; PEREIRA, H. B. B. O envelhecimento facial humano e sua mensuração - o passo inicial da prosoporrecognografia. Revista Sodebras v. 11, p. 67-71. 2016

SCOTT, I. M. L.; POUND, N.; STEPHEN, I. D.; CLARK, A. P.; PENTON-VOAK, I. S. Does Masculinity Matter? The Contribution of Masculine Face Shape to Male Attractiveness in Humans. PLoS ONE v. 5, n. 10, e13585. oct. 2010. https://doi.org/10.1371/journal.pone.0013585

SCOTT, N. J.; JONES, A. L.; KRAMER, R. S. S.; WARD R. Facial Dimorphism in Autistic Quotient Scores. Clin. Psychol. Sci. v. 3, n.2, p. 230-241. July. 2015. https://doi.org/ 10.1177/2167702614534238

SCOTT, N. J.; KRAMER, R. S. S.; JONES, A. L.; WARD R. Facial cues to depressive symptoms and their associated personality attributions. Psychiatry. Res. v. 208, n. 1, p. 47-53, jun. 2013.

https://doi.org/10.1016/j.psychres.2013.02.027

SIĞIRLI, D.; ERCAN, I. Growth and Allometry in Modern Morphometrics: Review. Turkiye. Klinikleri. J. Biostat. v. 5, n. 1, p. 42-8, 2013.

SLICE, D. E. Geometrics morphometrics. Annu. Rev. Anthropol. v. 36, p. 261-81, 2007. https://doi.org/10.1146/annurev.anthro.34.081804.120613

SNEATH, P. H.; SOKAL, R. R. Numerical taxonomy: The principles and practice of numerical classification. San Francisco: W.H. Freeman. 1973, 573p.

SOLON, C. C. E.; TORRES, M. A. J.; DEMAYO, C. G. Analyzing Shape of Faces of Hypertensive and NonHypertensive Males Using Geometric Morphometric Methods. JOMB v. 2, n. 2, p. 126-130, june, 2013. https://doi.org/10.12720/jomb.2.2.126-130 